\title{
Psychological Separation and Dimensions of Career Indecision in Secondary School Students
}

\author{
Paulo Jorge Santos \\ Faculty of Arts and Humanities, Porto State University, Porto, Portugal
}

and

Joaquim Luís Coimbra

Faculty of Psychology and Education, Porto State University, Porto, Portugal

\begin{abstract}
Lopez and Andrews (1987) interpreted career indecision as an indicator of the inadequate psychological separation of adolescents from their parents. However, various empirical studies have not managed to clearly demonstrated evidence of a relationship between systemic family variables and career indecision. This investigation, which involves a sample of 418 adolescents of both sexes in the 12th grade of secondary school, analyzed the relationship between conflictual and emotional independence and two dimensions of career indecision: developmental indecision and generalized indecision. As a principal methodology of statistical analysis, a canonical correlation analysis, one for each gender, was used. There were no relationships between the two sets of variables. The results were interpreted in light of the fact that some subjects could be classified as foreclosure in terms of identity status. A model of career decision status is proposed. (๑) 2000 Academic Press
\end{abstract}

Key Words: career decision making; career indecision; psychological separation; adolescence.

The role of the family as a fundamental influence on the career development of adolescents and young adults has been stressed by some classic theories of career development and choice (Roe, 1957; Super, 1957). However, the exact nature and degree of the family's influence on career decision making is not

This article is based on a Master of Psychology thesis submitted to the Faculty of Psychology and Education of Porto State University by the first author under the direction of the second author. This study was financed by a grant from Instituto de Inovação Educacional. A preliminary version of this article was presented at the 6th Biennial Conference of the European Association for Research on Adolescence, Budapest, Hungary, 3-7 June 1998. We thank Frederick Lopez, David Blustein, and two anonymous reviewers for their helpful comments and suggestions. We also express our gratitude to José Maia and Francisco Vitorino for their expert assistance with the data analysis.

Address correspondence and reprint requests to Paulo Jorge Santos, Faculty of Arts and Humanities, Porto State University, Apartado 55038, 4150-564 Porto, Portugal. E-mail: pjsosantos@mail. telepac.pt. 
completely understood. Furthermore, as Schulenberg, Vondracek, and Crouter (1984) have noted, research on the influence of the family on career development shows various limitations: (a) It focuses on results rather than on developmental processes, (b) it does not view the family as a functional whole, and (c) it fails to situate the family in the broader social context.

To address these shortcomings, some authors recommend using systemic family theories in the field of career psychology (e.g., Herr \& Lear, 1984). Specifically, Bratcher (1982) emphasized the issue of separation and autonomy concerning the family system as particularly important in the career decision making of many young people. In a similar way, Zingaro (1983) pointed out that subjects who presented pronounced difficulties in the career-choice process seem to evidence an undifferentiated self and a high degree of intergenerational fusion between parents and children (Bowen, 1978). Also using a systemic framework, Lopez and Andrews (1987) considered that career development and choice in adolescence cannot be separated from two important developmental tasks of this period: the construction of identity and psychological separation from the family. They emphasize how problems in the differentiation of the adolescent's self from the family system can be manifest as career indecision. The difficulty of some young people in choosing a career " . . . is indicative of inadequate parent-child separation, and, more generally, of the family's failure to achieve an appropriate structural change" (Lopez \& Andrews, 1987, p. 306). Career indecision could serve some systemic functions in the family, such as delaying the separation of one of its members or masking conflicts, like tensions and problems, between the marital couple.

The research carried out on Lopez and Andrews' (1987) propositions sought to analyze the relationships between family interactions and the career-decision process, especially career indecision. Eigen, Hartman, and Hartman (1987) used the circumplex model of Olson, Sprenkle, and Russel (1979) to analyze the family interaction patterns of a sample of participants classified as decided, developmental undecided, and chronic undecided. The initial hypothesis, which stated that career-decision status relates to specific patterns of family interactions, was not confirmed. They did identify an emergent association between chronic indecision and family systems characterized by low adaptability and high cohesion or high adaptability or low cohesion. Lopez (1989) tested a model that presupposed that low levels of vocational identity would be the result of anxiety and difficulties concerning academic adjustment in families with relationships characterized by marital conflict and low levels of psychological separation from parents. For both genders, the model accounted for a significant variance in the vocational identity scores. Kinnier, Brigman, and Noble (1990) found that the level of individuation toward the family of origin accounted for only $3 \%$ of the variance of career indecision and that the triangulation did not emerge as a significant predictor variable. Blustein, Wallbridge, Friedlander, and Palladino (1991) analyzed the relationship between several dimensions of psychological separation from parents and two career measures, career indecision and career 
decision-making self-efficacy. Using a canonical analysis, they did not find any relationship between the two sets of variables. Penick and Jepsen (1992) verified, in a sample of secondary school students and their parents, that the perception of the family functioning, at the level of family relationships and maintenance systems, predicted vocational identity and in a more substantial way than the variables related to socioeconomic status and academic achievement. More recently, Whiston (1996) found that women, but not men, who reported high levels of organization and control within their families also reported lower levels of career indecision, originating from a need for support in their career decisions, approach-approach conflicts concerning a number of attractive careers and feelings of confusion or diffusion about making a career decision.

As a whole, the results of these studies appear to be rather inconsistent. A possible explanation of these findings may lie in how career indecision was evaluated. Lopez (1989) and Penick and Jepsen (1992) used the Vocational Identity Scale (VIS; Holland, Daiger, \& Power, 1980), while the other researchers used the Career Decision Scale (CDS; Osipow, Carney, \& Barak, 1976), and Eigen et al.'s (1987) study used an evaluation procedure related to the number of times that the participants had changed their career options in a given period of time. The CDS and VIS are similar instruments, although they differ in origin and rationale (Holland, Johnston, \& Asama, 1993). In spite of the high correlations between the results of the two instruments (Fretz \& Leong, 1982; Fuqua \& Hartman, 1983; Fuqua, Seaworth, \& Newman, 1987; Graef, Wells, Hyland, \& Muchinsky, 1985; Holland et al., 1993; Leong \& Morris, 1989), a study by Tinsley, Bowman, and York (1989) demonstrated that vocational identity scales are not factorially equivalent to career-indecision scales.

A second explanation, which we consider more plausible, lies in the way in which career indecision was conceptualized. Most of the research which sought to analyze the relationship between systemic family variables and career indecision assumed that the latter is a unidimensional construct. However, an increasing number of authors have proposed that undecided individuals do not represent a group of homogenous characteristics and that career indecision should be conceptualized as a multidimensional construct (Betz, 1992; Callanan \& Greenhaus, 1992; Chartrand \& Camp, 1991; Fuqua, Blum, \& Hartman, 1988; Holland \& Holland, 1977; Larson, Heppner, Ham, \& Dugan, 1988; Lucas \& Epperson, 1988, 1990; Rojewsky, 1994; Savickas \& Jarjoura, 1991; Sepich, 1987; Wanberg \& Muchinsky, 1992). This evolution is reflected in the emergence of second-generation instruments (see Savickas, 1992) which evaluate different dimensions of career indecision, such as the Career Decision Profile (CDP; Jones, 1989) or the Career Factors Inventory (CFI; Chartrand, Robbins, Morril, \& Boggs, 1990).

Although there is some controversy about the different types of careerundecided individuals (for a review, see Gordon, 1998), there has been a relative consensus in distinguishing simple or developmental indecision, which corresponds to a normal phase, in developmental terms, of exploration of alternatives, 
and the chronic or generalized indecision, reflecting difficulties in the decisionmaking process in other aspects of the subject's life (Betz, 1992; Crites, 1969, 1981; Haag-Mutter, 1986; Lewko, 1994; Salomone, 1982; Tyler, 1969). Indecisive individuals are characterized by high levels of anxiety, external locus of control, low self-esteem, and inadequate identity formation (Fuqua \& Hartman, 1983; Hartman, 1990; Hartman \& Fuqua, 1983; Johnson, 1990; Salomone, 1982), and for these individuals a more prolonged intervention, approaching a psychotherapeutic process, is needed (Hartman, 1990; Heppner \& Hendricks, 1995; Salomone, 1982).

The studies that analyzed the influence of systemic family variables in the manifestation of career indecision opted, in most cases, to consider the latter a unidimensional construct, ignoring the evolution registered at a theoretical level and at the level of the empirical research to which we have already referred. Therefore, it is possible that the relationships between these variables demonstrate an inconsistent pattern because they confuse different types of career indecision. We should remember that the research which sought to analyze differences, in terms of psychological characteristics, between career-decided and -undecided individuals also produced inconsistent results (Dosnon, 1996; Gordon, 1995; Slaney, 1988), possibly because it did not consider the existence of different types of career undecided individuals (Betz, 1992; Holland \& Holland, 1977; Phillips, 1992; Phillips \& Pazienza, 1988).

The only two studies that analyzed various dimensions of career indecision, as far the research on the influence of family systemic variables is concerned, are Eigen et al.'s (1987) and Whiston's (1996). On one hand, Eigen et al. expressly recommended a direct evaluation of the career-indecision dimensions instead of a criteria based on the number of times the participants change career options. On the other hand, Whiston used four factors identified in the CDS by Shimizu, Vondracek, Schulenberg, and Hostetler (1988); Schulenberg, Shimizu, Vondracek, and Hostetler (1988); and Vondracek, Hostetler, Schulenberg, and Shimizu (1990). However, the factorial structure of the CDS has been the object of some controversy (see Martin, Sabourin, Laplante, \& Coallier, 1991), and the principal author of the scale, Osipow, recommends the use of the global result of the scale instead of results from subscales, despite the fact that career indecision is considered by him a complex phenomenon (Osipow, 1991, 1994).

The present research analyzed the relationship between psychological separation, defined as the perception of conflictual and emotional independence from parents, and two types of career indecision, simple or developmental career indecision and generalized indecision. Following Lopez and Andrews' (1987) premises, we tested the hypothesis that low levels of psychological separation relate to high levels of developmental and generalized career indecision.

The second objective for this study was to analyze possible gender differences in the relationship between psychological separation and dimensions of career indecision. Although Lopez and Andrews (1987) did not speculate about gender differences, some studies have highlighted differences between men and women 
regarding the influence that systemic factors may play in the emergence and maintenance of career indecision (Lopez, 1989; Whinston, 1996). Simultaneously, research has ascertained the existence of gender differences in two of the variables used in this study, with women normally demonstrating lower levels of psychological separation regarding parental figures (Allen \& Stoltenberg, 1995; Lapsley et al., 1989; Lopez, 1989; Lucas, 1997; Thomason \& Winer, 1994), which seems to stress the importance of significant personal relationships and attachments in the process of female socialization (Gilligan, 1982; Josselsson, 1988) and higher levels of generalized indecision (Chartrand et al., 1990; Lewis \& Savickas, 1995). Thus, a differentiated analysis is justified for each gender.

\section{METHOD}

\section{Participants}

The participants consisted of 418 12th-grade students, between the ages of 16 and 22 , with a mean age of 17.4 years $(S D=.77)$. There were $240(57.4 \%)$ female students and $178(42.6 \%)$ male students. The volunteers were recruited from classes, in a nonrandom way, in 10 Portuguese schools ( 9 public schools and 1 private school). Since we intended to evaluate the psychological separation from parents, only students with two living parents (even if the parents were divorced or separated) were included in the study.

\section{Procedure and Instruments}

The administration of the instruments took place in school. The participants were informed that the general purpose of this research consisted of studying how they made decisions about several aspects of their lives. The volunteer nature of the participation was emphasized and the confidentiality of the results guaranteed.

Measurement of psychological separation. For the evaluation of the psychological separation from parents, we used the Psychological Separation Inventory (PSI; Hoffman, 1984). This questionnaire consists of 138 items divided into eight scales, four regarding the father and four regarding the mother. The scales measure four dimensions of psychological separation: Functional Independence (FI; 26 items), which evaluates the ability to deal independently with personal matters without parental help; Emotional Independence (EI; 34 items), which evaluates the freedom from an excessive need for approval, closeness, and emotional support from parents; Conflictual Independence (CI; 50 items), which evaluates the absence of guilt, anxiety, distrust, anger, inhibition, or resentment toward parents; and Attitudinal Independence (AI; 28 items), which evaluates the values, attitudes, and beliefs that differ from those of one's parents. The PSI uses a 5-point Likert-type scale $(0=$ not at all true of me to $4=$ very true of $m e)$. The scores for the items are added and then subtracted from the total number possible for each scale so that higher values reflect a higher level of independence from 
parents. Hoffman presented high estimates of internal consistency (Cronbach's $\alpha$ ) for the several scales, with values ranging from .84 to .92. Other authors presented similar results (Lapsley, Rice, \& Shadid, 1989; Lopez, 1989; Rice, 1992). Hoffman presented 2- to 3-week test-retest reliabilities (Pearson's correlation coefficient) which ranged from .49 to .94 (median $=.83$ ) for a male sample and from .70 to .96 (median $=.83$ ) for a female sample. The construct validity was analyzed by Hoffman through a confirmatory factor analysis separating items related to mother and father. The factorial structure fit the proposed theoretical framework. Evidence from the construct validity of the PSI can be inferred from the association between psychological separation and several psychological adjustment variables, such as academic adjustment and the absence of interpersonal problems (Hoffman, 1984; Hoffman \& Weiss, 1987; Lopez \& Gover, 1993; Lopez, Watkins, Manus, \& Hunton-Shoup, 1992; Rice, Cole, \& Lapsley, 1990). Still, regarding the construct validity, two studies showed that the independence from parents tends to increase with age for most scales (Lapsley et al., 1989; Rice, 1992).

In this research we used the Portuguese version of the PSI (Almeida, Dias, \& Fontaine, 1996). Some modifications to the questionnaire were introduced in the process of adaptation of the instrument. The first consisted in marking some items with an asterisk, which presupposed that the subject was not living at home during the school year, a situation which always occurred in the original sample. Individuals were informed in the instructions for filling in the questionnaire that they should imagine themselves living away from their parents during the school period in case this situation did not really occur. Another change consisted of altering the answer alternatives $(1=$ not at all true of me to $4=$ very true of me $)$ to avoid the possibility of an intermediate response. Higher results represent less independence from parents. Almeida et al. eliminated from the final version of the questionnaire all nondiscriminative items (i.e., those which concentrated more than $50 \%$ of answers in a given answer alternative) and carried out a principal-axis factor analysis with varimax rotation with a sample of 220 university students (105 females and 115 males) with a mean age of 20.5 years, confirming the four factors almost exactly the way Hoffman (1984) did, although some items loaded different factors in the Portuguese sample. The Portuguese version has a total of 88 items, 44 for each parental figure. The majority of the items from the several scales are a subgroup of the equivalent scales of the original questionnaire. The internal consistency values (Cronbach's $\alpha$ ) ranged from .82 to .89 . Research by Dias (1996), with a sample of Portuguese college students, led to the verification that the correlation pattern of the PSI with a set of indicators of psychological adaptation were very similar to that found in studies carried out with American samples, which allowed us to sustain the validity of the questionnaire in the Portuguese cultural context. A principal-axis factor analysis with varimax rotation with a sample of secondary school students confirmed the factor structure of the scale evidenced in the adaptation process of the PSI into Portuguese (Santos, 1997). In the present study, we decided to use 
only the Conflictual Independence (11 items for each parental figure) and Emotional Independence (11 items for each parental figure) scales, as these scales more adequately evaluate the hypotheses that we wanted to test and have demonstrated more consistent relationships with a related set of variables (Baker, 1990). The estimated internal consistency values (Cronbach's $\alpha$ ) for these scales in this study range from .80 to .92 . Sixteen-day test-retest reliability (Pearson's correlation coefficient), estimated for a sample of 48 students from the 12th grade (18 males and 30 females), ranged from .84 to .93 (Santos, 1997).

Measurement of generalized indecision. For the evaluation of generalized indecision, we used the Indecisiveness Scale (IS; Frost \& Shows, 1993). This 15-item scale evaluates the degree of inability to make decisions. It uses a 5-point Likert-type scale $(1=$ strongly disagree to $5=$ strongly agree $)$, with higher results reflecting a greater level of generalized indecision. Frost and Shows verified, in a sample of university students, that individuals with higher scores on this scale showed higher levels of procrastination and greater difficulties in decision making in several aspects of their lives, including academic, social, and family levels; simultaneously, they exhibited longer decision-making latencies in a series of choice tasks taking place in a laboratory context. Gayton, Clavin, Clavin, and Broida (1994) verified that university students who had not yet chosen a major showed higher results of generalized indecision when compared to those who had already made their major choice. The internal consistency (Cronbach's $\alpha$ ) of IS was good, ranging from .80 to .90 (Frost \& Gross, 1993; Frost \& Shows, 1993; Gayton et al., 1994).

To adapt the scale, we translated the IS into Portuguese (all the translations were done by the first author and revised by the second author) according to some suggestions proposed by Van de Vijver and Hambleton (1996) for the translation of tests in cross-cultural research. We altered the answer alternatives which, in the Portuguese version, uses a 6-point Likert-type scale $(1=$ strongly disagree to 6 = strongly agree), to avoid the possibility of an intermediate answer. This procedure, apart from generating greater variability in the scores, further possesses the advantage of ". . .ensuring that the underlying dimension will be linear or can be made linear" (Dawis, 1987, p. 482). The estimated internal consistency (Cronbach's $\alpha$ ) of IS in this investigation was .78. Sixteen-day test-retest reliability (Pearson's correlation coefficient), estimated for a sample of 48 students (18 males and 30 females), was .85 (Santos, 1997). High results in the IS were negatively correlated with the degree of career certainty in a sample of 12th-grade students (Santos, 1997).

Measurement of developmental indecision. With the objective of evaluating developmental indecision, we used the Career Factors Inventory (CFI; Chartrand et al., 1990). The CFI is a 21-item multidimensional measure of antecedents of career indecision. Two of them are personal-emotional antecedents (Career Choice Anxiety and Generalized Indecisiveness), while the other two are informational antecedents (Need for Career Information and Need for SelfKnowledge). The Career Choice Anxiety (CCA; 6 items) scale measures the level 
of reported anxiety that is attached to the career decision-making process. The Generalized Indecisiveness (GI; 5 items) scale measures the degree of inability to make decisions, even when the necessary conditions for decision making exist. The Need for Self-Knowledge (NFSK; 4 items) scale measures the need for self-definition and discovery. Last, the Need for Career Information (NFCI; 6 items) scale measures the perceived need to acquire factual data and experience concerning various occupations prior to making career commitments. The CFI uses a 5 -point Likert-type scale $(1=$ strongly disagree to $5=$ strongly agree $)$ and in some items the choice is made between two antonyms (e.g., tense and relaxed). Higher scores indicate that more importance is given to the evaluated dimension of career indecision. The internal consistency (Cronbach's $\alpha$ ) ranged from .73 to .86 (Chartrand et al., 1990). Other authors obtained similar results (Chartrand \& Robbins, 1990; Lewis \& Savickas, 1995). The test-retest reliability (Pearson's correlation coefficient) ranged from .79 to .84 for the various scales, with a mean of .80 (Chartrand et al., 1990) over a 2-week interval period. The construct validity of the CFI was tested using both confirmatory factor analysis (Chartrand et al., 1990) and principal components analysis (Lewis \& Savickas, 1995) and the results confirm the four-factor model. At the concurrent validity level of CFI, it was verified that the scales correlated, in theoretically expected directions, with a set of measures which included vocational identity, selfesteem, and goal instability (for a review, see Chartrand \& Nutter, 1996).

For the adaptation of the scale we translated the CFI into Portuguese and altered the answer alternatives, which, in the Portuguese version, use a 6-point Likert-tipe scale. Using a principal-axis factor analysis with varimax rotation, with a 12th-grade student sample, Santos (1997) extracted only two factors, based on the analysis of the scree test and the eigenvalues. The first factor was formed by the items of CCA and GI scales and was designated Generic Indecision (GIND), assessing, as the IS, the difficulty and anxiety in the process of decision making. The second factor was formed by items from the NFSK and NCFI scales and was designated Need for Career Exploration (NFCE); it evaluates the subject's personal perception about the need to exploring his/her self and the world of work. The differences between the factorial structures of the CFI with the original American sample and the present Portuguese sample may be due to several factors, namely the individuals' ages (the average age of the Portuguese sample is approximately 3 years younger than that of the sample used in the original validation process). In this research, the internal consistency (Cronbach's $\alpha$ ) of GIND was .86 and of NFCE .80. Sixteen-day test-retest reliability (Pearson's correlation coefficient), estimated from a sample of 48 students from the 12th grade (18 males and 30 females), was .84 for GIND and .71 for NFCE (Santos, 1997). Scores on both scales were negatively correlated with the degree of career certainty in a sample of 12th-grade students (Santos, 1997). In the case of the current research, we used the items that loaded on the NFCE factor as a measure of developmental indecision. 
TABLE 1

Pearson Correlation Coefficients of the Six Variables

$\begin{array}{llllll}1 & 2 & 3 & 4 & 5 & 6\end{array}$

1. Conflictual Independence-mother (PSI)

2. Conflictual Independence-father (PSI)

$\begin{array}{rcccc}.52 * * & & & & \\ -.37 * * & -.16 * * & & & \\ -.19 * * & -.46^{* *} & .66^{* *} & & \\ .04 & .08 & .17 * * & .12 * & \\ .14 * * & .19 * * & .11 * & .01 & .29 * *\end{array}$

3. Emotional Independence-mother (PSI)

4. Emotional Independence-father (PSI)

5. Need for Career Exploration (CFI)

6. Generalized Indecision (IS)

$14^{* *}$

$.19^{*}$

$\begin{aligned} * p & <.05 . \\ * * p & <.01 .\end{aligned}$

\section{RESULTS}

The correlational matrix of all the variables used in this study is displayed in Table 1. In a group of eight possible correlations among the four scales of independence from parents and the two dimensions of career indecision, five are statistically significant in the expected directions. However, the magnitude of the correlations is small.

Table 2 presents mean scores and standard deviations for each measure. A one-way ANOVA revealed gender differences at the level of psychological separation in three of the scales, with females showing less independence from their parents: at the level of the conflictual independence scale-father, $F(1$, $410)=4.45, p<.05$; at the level of emotional independence scale-mother, $F(1,413)=34.54, p<.0001 ;$ and at the level of emotional independence

TABLE 2

Means and Standard Deviations of Measures of Need for Career Exploration, Generalized Indecision, and Psychological Separation

\begin{tabular}{|c|c|c|c|c|}
\hline \multirow[b]{2}{*}{ Scale } & \multicolumn{2}{|c|}{ Male } & \multicolumn{2}{|c|}{ Female } \\
\hline & $M$ & $S D$ & $M$ & $S D$ \\
\hline \multicolumn{5}{|l|}{ Career Factors Inventory } \\
\hline Need for Career Exploration & 40.87 & 8.82 & 42.24 & 9.89 \\
\hline Indecisiveness Scale & 44.61 & 9.06 & 48.34 & 10.03 \\
\hline \multicolumn{5}{|l|}{ Psychological Separation Inventory } \\
\hline Emotional Independence_father & 26.90 & 5.97 & 29.46 & 7.43 \\
\hline Emotional Independence-mother & 28.76 & 5.35 & 32.08 & 5.94 \\
\hline Conflictual Independence-father & 23.59 & 6.06 & 24.91 & 6.39 \\
\hline Conflictual Independence-mother & 24.10 & 5.42 & 23.56 & 5.23 \\
\hline
\end{tabular}

Note. The potential ranges for the several instruments are as follows: Need for Career Exploration (10-60); Indecisiveness Scale (15-90); Emotional Independence-father (11-44); Emotional Independence-mother (11-44); Conflictual Independence-father (11-44); Conflictual Independence - mother (11-44). 
scale-father, $F(1,412)=14.12, p<.0001$. There were no gender differences in the results of the conflictual independence scale-mother, $F(1,415)=.30$, ns. These differences are compatible with the ones earlier observed in other researches in which the PSI was used (for a review, see Lopez \& Gover, 1993). Females also reported higher IS scores than did males, $F(1,412)=15.21, p<$ .001 . During the process of validation of IS, gender differences were not the object of evaluation because the original sample consisted solely of female subjects (Frost \& Shows, 1993). However, similar gender differences have been reported in other investigations that evaluate indecisiveness (Chartrand et al., 1990; Lewis \& Savickas, 1995).

To analyze the degree of association between the variables related to the psychological separation from parents and the two dimensions of career indecision, we used a canonical correlation analysis. The conflictual (mother and father) and emotional (mother and father) independence from parents formed the set of independent variables, and the developmental and generalized career indecision formed the set of dependent variables. Because we intended to research possible gender differences, and considering the observed differences between male and female in several measures, we decided to use a canonical correlation for each gender. For males, $\chi^{2}(8)=.91, n s$. For females, $\chi^{2}(8)=.90$, $n s$. Faced with these results, we decided to combine men and women into one single sample and carry out a new canonical correlation. The results were equally nonsignificant: $\chi^{2}(8)=.92, n s$. These results do not permit support for the hypothesis regarding the relations between the psychological separation and dimensions of career indecision for both genders.

Although it was not predictable, given the dimension of our sample, that the absence of significant results was due to an insufficient number of individuals, we conducted a power analysis, based on the $\alpha$ level .05, according to Cohen's recommendations (Cohen, 1988, Ch. 10). The values found were $96 \%$ for the female sample, $99 \%$ for the male sample, and $99 \%$ for the total sample.

\section{DISCUSSION}

Contrary to the hypotheses we advanced, based on the propositions of Lopez and Andrews (1987), we did not find significant relationships, for both genders, between the four dimensions of psychological separation and either developmental career indecision or generalized indecision. This result approaches those found by Eigen et al.'s (1987) and Blustein et al.'s (1991) studies and, to some extent, to the result presented by Kinnier et al. (1990). Blustein et al. (1991) explained the absence of relationships between psychological separation, on the one hand, and career indecision and career decision-making self-efficacy, on the other hand, as the result of a complex pattern of relationships between the two sets of variables. According to these authors, in some cases, low levels of psychological separation from parents may result in career indecision, while in others it may result in foreclosure choices, i.e., career choices which do not result from an autonomous process of career exploration, having been conditioned by 
the parents or other parental-type figures. We think that the same type of explanation may be applied to the relationships between psychological separation and the two dimensions of career indecision, either developmental indecision or generalized indecision. Sometimes low levels of psychological separation may correlate with high levels of generalized indecision, as some authors have stressed (Hartman, 1990; Johnson, 1990; Lopez, 1983; Salomone, 1982), while in other cases the result may turn out to be the opposite, and the individual does not experience decision-making problems. In some situations, individuals with low levels of psychological separation could feel the need to initiate or intensify the process of career exploration, aiming to overcome the difficulties at the level of career choices, while others, who would be included in the foreclosure identity status, according to our interpretation, may not acknowledge the need to engage in career exploration, since their choices have already been made, although their level of psychological separation from parents is low. Research based in the identity status model (Marcia, 1966, 1980, 1987) show that foreclosure identity status individuals are very close to their parents, finding it difficult to differentiate from their families of origin, which tend to encourage conformity and adhesion to family values (Kroger, 1996, 1998; Marcia, 1986; Muuss, 1996). Research has also demonstrated that a significant percentage of secondary school and college students are foreclosures (Petitpas, 1978), thus giving our interpretation of the results a higher degree of plausibility. In a study with a sample of Portuguese college students that percentage reached 40\% (Costa \& Campos, 1986).

This possible explanation for our results finds some support in a research by Brisbin and Savickas (1994) wherein three of the most well-known evaluation scales of career indecision, the CDS (Osipow et al., 1976), the VIS (Holland et al., 1980), and the CDP (Jones, 1989), managed to discriminate the diffusion and moratorium statuses, with the first status showing a higher level of indecision, as expected. However, none of the scales managed to discriminate the foreclosure from the achieved identity status. The authors affirm that this result validates the scales of career indecision in the sense they were never conceived to differentiate the achieved from the foreclosure identity status, but conclude that low levels in career indecision scales may be the result of pseudocrystallized choices. Foreclosed individuals need an intervention that promotes the exploration of alternatives beyond the ones encouraged by parental figures (Marcia, 1986; Petitpas, 1978; Raskin, 1989). It is quite unlikely that this type of intervention will occur if the results of these scales constitute the only diagnosis elements and are not seen as a reflection of a rather limited aspect of the career-choice process (Blustein, Pauling, DeMania, \& Faye, 1994).

In short, the conclusion that we can draw from the analysis of the results of this research supports Blustein et al.'s (1991) study, allowing, simultaneously, an expansion of their conclusions: Individuals with low levels of psychological separation from their parents may be found at both ends of the two types of career indecision we considered, generalized and developmental indecision.

However, we must consider the limitations of this study. First, the instruments 
used were self-report scales and they could have been influenced by socialdesirability processes. Second, our interpretation about the absence of relationships between psychological separation and dimensions of career indecision should be accepted carefully because identity statuses of the sample individuals have not been evaluated.

Despite these limitations, this study strengthens the need to analyze the quality of career decisions, using either interview methods or more sensitive self-report items, by trying to distinguish those resulting from an autonomous process of career exploration (the crystallized) from those which were dictated by parental figures (the pseudocrystallized). The traditional evaluation instruments of career indecision do not seem capable of answering to this need, due both to their characteristics and to the subjacent theoretical basis. The theoretical approach which best allows the distinction between both types of indecision is the ego identity status model of Marcia (1966, 1980, 1987). As Raskin (1985) so rightly ascertains, only ". . . identity theorists observe the quality of commitment. There is no room in career development theory to account for the wholesale adoption of parental values or the unexamined choice, once the decision has been made" (Raskin, 1985, pp. 31-32).

We consider that it is possible to conceptualize four statuses of career decision, based on the psychological processes of career exploration and investment, parallel to Marcia's identity statuses, which configure different modes of career identity. Therefore, we consider two types of decision: autonomous decision (career investment preceded by career exploration) and foreclosed decision (career investment without previous career exploration). Individuals who present decisions of this nature will, predictably, obtain low scores on career indecision evaluation instruments. Likewise, two types of indecision are considered: developmental indecision (absence of career investment and presence of career exploration) and diffuse indecision (absence of career investment and career exploration). It is possible that this latter type of indecision is similar to chronic indecision or indecisiveness, which has been described by several authors (Crites, 1969, 1981; Fuqua \& Hartman, 1983; Hartman \& Fuqua, 1983; Salomone, 1982; Tyler, 1969). Individuals of these two statuses will, most probably, obtain high scores on career-indecision scales.

The proposal of this model of career decision statuses allows us to converge the processes of career choice and career indecision with the processes of identity construction. In this way, the attempt to integrate two dimensions of human development, career development and identity development, is reinforced. This effort is patent in the theoretical proposals and empirical research of Blustein and colleagues (Blustein, Devenis, \& Kidney, 1989; Blustein \& Noumair, 1996; Blustein \& Phillips, 1990) and Vondracek and colleagues (Skorikov \& Vondracek, 1998; Vondracek, 1992; Vondracek, Schulenberg, Skorikov, Gillespie, \& Wahlheim, 1995). Therefore, the limitations that have been pointed out in the research on career indecision, and which are basically related to the absence of a solid theoretical framework in many of the studies (Hall, 1992; Tinsley, 1992), 
can be overcome by the integration of this construct in a broader conceptual approach, as some authors have claimed (Chartrand et al., 1994).

However, analyzing career decisions based on the decision statuses that we outlined should not make us forget the contexts, particularly the family context, in which the individuals come to construct diverse forms of dealing with the demands of career choices. In this domain, systemic family approaches may permit a deeper understanding of the adolescents' processes of career decision. For example, we can expect that emeshed and disengaged families correspond more readily to statuses of foreclosed decision or diffuse decision. Similarly to the proposals of Sabatelli and Mazor (1985), who drew attention to the need to analyze individuation as part of the process of identity construction and the level of differentiation within the family system as interdependent phenomena, we consider an integration between an approach of a systemic nature with another that emphasizes the individual developmental issues of identity and career choice as a promising path that research should investigate further.

\section{REFERENCES}

Almeida, M. J. V., Dias, G. F., \& Fontaine, A. M. (1996). Separação psicológica das figuras parentais em jovens universitários: Adaptação do "Psychological Separation Inventory" de Hoffman à população portuguesa [Psychological separation from parents of college young adults: Adaptation of Hoffman's Psychological Separation Inventory for the Portuguese population]. Psiquiatria Clínica, 17, 5-17.

Allen, S. F., \& Stoltenberg, C. D. (1995). Psychological separation of older adolescents and young adults from their parents: An investigation of gender differences. Journal of Counseling and Development, 73, 542-546.

Baker, R. W. (1990). A tale of two tests: Problems in the co-use of two instruments. Unpublished manuscript, Clark University.

Betz, N. E. (1992). Career assessment: A review of critical issues. In S. D. Brown \& R. W. Lent (Eds.), Handbook of counseling psychology (2nd ed., pp. 453-484). New York: Wiley.

Blustein, D. L., Devenis, L. E., \& Kidney, B. A. (1989). Relationship between identity formation process and career development. Journal of Counseling Psychology, 36, 196-202.

Blustein, D. L., \& Noumair, D. A. (1996). Self and identity in career development: Implications for theory and practice. Journal of Counseling and Development, 74, 433-441.

Blustein, D. L., Pauling, M. L., DeMania, M. E., \& Faye, M. (1994). Relation between exploratory and choice factors and decisional progress. Journal of Vocational Behavior, 44, 75-90.

Blustein, D. L., \& Philipps, S. D. (1990). Relation between ego identity statuses and decision-making styles. Journal of Counseling Psychology, 37, 160-168.

Blustein, D. L., Walbridge, M. M., Friedlander, M. L., \& Palladino, D. E. (1991). Contributions of psychological separation and parental attachment to the career development process. Journal of Counseling Psychology, 38, 39-50.

Bowen, M. (1978). Family therapy in clinical practice. New York: Jason Aronson.

Bratcher, W. E. (1982). The influence of the family on career selection: A family systems perspective. Personnel and Guidance Journal, 61, 87-91.

Brisbin, L. A., \& Savickas, M. L. (1994). Career indecision scales do not measure foreclosure. Journal of Career Assessment, 2, 352-363.

Callanan, G. A., \& Greenhaus, J. H. (1992). The career indecision of managers and professionals: An examination of multiple subtypes. Journal of Vocational Behavior, 41, 212-231.

Chartrand, J. M., \& Camp, C. C. (1991). Advances in the measurement of career development constructs: A 20-year review. Journal of Vocational Behavior, 39, 1-39. 
Chartrand, J. M., Martin, W. F., Robbins, S. B., McAuliffe, G. J., Pickering, J. W., \& Calliotte, J. A. (1994). Testing a level versus an interactional view of career indecision. Journal of Career Assessment, 2, 55-69.

Chartrand, J. M., \& Nutter, K. J. (1996). The Career Factors Inventory: Theory and applications. Journal of Career Assessment, 4, 205-218.

Chartrand, J. M., \& Robbins, S. B. (1990). Using multidimensional career decision instruments to assess career decidedness and implementation. Career Development Quarterly, 39, 166-177.

Chartrand, J. M., Robbins, S. B., Morril, W. H., \& Boggs, K. (1990). Development and validation of the Career Factors Inventory. Journal of Counseling Psychology, 37, 491-501.

Cohen, J. (1988). Statistical power analysis for the behavioral sciences (2nd ed.). Hillsdale, NJ: Erlbaum.

Costa, M. E., \& Campos, B. P. (1986). Identidade de estudantes universitários: Diferenças de curso e de sexo [Identity of college students: course and sex differences]. Cadernos de Consulta Psicológica, 2, 5-11.

Crites, J. O. (1969). Vocational psychology. New York: McGraw-Hill.

Crites, J. O. (1981). Career counseling. New York: McGraw-Hill.

Dawis, R. V. (1987). Scale construction. Journal of Counseling Psychology, 34, 481-489.

Dias, M. G. (1996). Tarefas desenvolvimentais e bem-estar psicológico dos jovens [Developmental tasks and psychological well-being of young adults]. Unpublished doctoral dissertation, Faculty of Psychology and Education, Porto State University, Portugal.

Dosnon, O. (1996). L'indécision face aux choix scolaire ou professionnel: Concepts et mesures [Indecision concerning educational and career choices: Concepts and measures]. L'Orientation Scolaire et Professionnele, 25, 129-168.

Eigen, C. A., Hartman, B. W., \& Hartman, P. T. (1987). Relations between family interaction patterns and career indecision. Psychological Reports, 60, 87-94.

Fretz, B. R., \& Leong, F. T. L. (1982). Career development status as a predictor of career intervention outcomes. Journal of Counseling Psychology, 9, 388-393.

Frost, R. O., \& Gross, R. C. (1993). The hoarding of possessions. Behavior Research Therapy, 31, 367-381.

Frost, R. O., \& Shows, D. L. (1993). The nature and measurement of compulsive indecisiveness. Behavior Research Therapy, 31, 683-692.

Fuqua, D. R., Blum, C. R., \& Hartman, B. W. (1988). Empirical support for the differential diagnosis of career indecision. Career Development Quarterly, 36, 364-373.

Fuqua, D. R., \& Hartman, B. W. (1983). Differential diagnosis and treatment of career indecision. Personnel and Guidance Journal, 62, 27-29.

Fuqua, D. R., Seaworth, T. B., \& Newman, J. L. (1987). The relationship of career indecision and anxiety: A multivariate examination. Journal of Vocational Behavior, 30, 175-186.

Gayton, W. F., Clavin, R. H., Clavin, S. L., \& Broida, J. (1994). Further validation of the Indecisiveness Scale. Psychological Reports, 75, 1631-1634.

Gilligan, C. (1982). In a different voice: Psychological theory and women's development. Cambridge, MA: Harvard Univ. Press.

Gordon, V. N. (1995). The undecided college student: An academic and career advising challenge (2nd ed.). Springfield, IL: Charles Thomas.

Gordon, V. N. (1998). Career decidedness types: A literature review. Career Development Quarterly, 46, 386-403

Graef, M. I., Wells, D. L., Hyland, A. M., \& Muchinsky, P. M. (1985). Life history antecedents of vocational indecision. Journal of Vocational Behavior, 27, 276-297.

Haag-Mutter, P. (1986). Career indecision (ERIC Document Reproduction Service No. ED 286 143).

Hall, D. T. (1992). Career indecision research: Conceptual and methodological problems [Comment]. Journal of Vocational Behavior, 41, 245-250.

Hartman, B. W. (1990). Endless unacceptable alternatives: The case of Sondra. Career Development Quarterly, 39, 40-43. 
Hartman, B. W., \& Fuqua, D. R. (1983). Career indecision from a multidimensional perspective: A reply to Grites. School Counselor, 30, 340-346.

Heppner, M. J., \& Hendricks, F. (1995). A process and outcome study examining career indecision and indecisiveness. Journal of Counseling and Development, 73, 426-437.

Herr, E. L., \& Lear, P. B. (1984). The family as an influence on career development. Family Therapy Collections, 10, 1-15.

Hoffman, J. A. (1984). Psychological separation of late adolescents from their parents. Journal of Counseling Psychology, 31, 170-178.

Hoffman, J. A., \& Weiss, B. (1987). Family dynamics and presenting problems in college students. Journal of Counseling Psychology, 34, 157-163.

Holland, J. L., Daiger, D. C., \&, Power, P. G. (1980). Manual for My Vocational Situation. Palo Alto, CA: Consulting Psychologists Press.

Holland, J. L., \& Holland, J. E. (1977). Vocational indecision: More evidence and speculation. Journal of Vocational Behavior, 24, 404-414.

Holland, J. L., Johnston, J. A., \& Asama, N. F. (1993). The Vocational Identity Scale: A diagnostic and treatment tool. Journal of Career Assessment, 1, 1-12.

Johnson, D. P. (1990). Indecisiveness: A dynamic, integrative approach. Career Development Quarterly, 39, 34-39.

Jones, L. K. (1989). Measuring a three-dimensional construct of career indecision among college students: A revision of the Vocational Decision Scale-The Career Decision Profile. Journal of Counseling Psychology, 36, 477-486.

Josselson, R. (1988). The embedded self: I and thou revisited. In D. K. Lapsley \& F. C. Power (Eds.), Self, ego, and identity: Integrative approaches (pp. 91-106). New York: Springer-Verlag.

Kinnier, R. T., Brigman, S. L., \& Noble, F. C. (1990). Career indecision and family enmeshment. Journal of Counseling and Development, 68, 309-312.

Kroger, J. (1996). Identity in adolescence: The balance between self and other (2nd ed.). London. Routlege.

Kroger, J. (1998). Adolescence as a second separation-individuation process. In E. E. Skoe \& A. L. von der Lippe (Eds.), Personality development in adolescence: A cross national and life span perspective (pp. 172-192). London: Routledge.

Lapsley, D. K., Rice, K. G., \& Shadid, G. E. (1989). Psychological separation and adjustment to college. Journal of Counseling Psychology, 36, 286-294.

Larson, L. M., Heppner, P. P., Ham, T., \& Dugan, K. (1988). Investigating multiple subtypes of career indecision through cluster analysis. Journal of Counseling Psychology, 35, 439-446.

Leong, F. T. L., \& Morris, J. (1989). Assessing the construct validity of Holland, Daiger, and Power's measure of Vocational Identity. Measurement and Evaluation in Counseling and Development, 22, 117-125.

Lewis, D. M., \& Savickas, M. L. (1995). Validity of the Career Factors Inventory. Journal of Career Assessment, 3, 44-56.

Lewko, J. H. (1994). The evaluation of career indecision in career development. Canadian Journal of Counselling, 28, 281-289.

Lopez, F. G. (1983). A paradoxical approach to vocational indecision. Personnel and Guidance Journal, 61, 410-412.

Lopez, F. G. (1989). Current family dynamics, trait anxiety, and academic adjustment: Test of a family-based model of vocational identity. Journal of Vocational Behavior, 35, 76-87.

Lopez, F. G., \& Andrews, S. (1987). Career indecision: A family systems perspective. Journal of Counseling and Development, 65, 304-307.

Lopez, F. G., \& Gover, M. R. (1993). Self-report measures of parent-adolescent attachment and separation-individuation: A selective review. Journal of Counseling and Development, 71, 560-569.

Lopez, F. G., Watkins, C. E., Jr., Manus, M., \& Hunton-Shoup, J. (1992). Conflictual independence, mood regulation, and generalized self-efficacy: Test of a model of late-adolescent identity. Journal of Counseling Psychology, 39, 375-381. 
Lucas, M. (1997). Identity development, career development, and psychological separation from parents: Similarities and differences between men and women. Journal of Counseling Psychology, 44, 123-132.

Lucas, M., \& Epperson, D. (1988). Personality types in vocationally undecided students. Journal of College Student Development, 29, 460-466.

Lucas, M. S., \& Epperson, D. L. (1990). Types of vocational undecidedness: A replication and refinement. Journal of Counseling Psychology, 37, 382-388.

Marcia, J. E. (1966). Development and validation of ego identity status. Journal of Personality and Social Psychology, 3, 551-558.

Marcia, J. E. (1980). Identity in adolescence. In J. Adelson (Ed.), Handbook of adolescent psychology (pp. 159-187). New York: Wiley.

Marcia, J. E. (1986). Clinical implications of the identity status approach within psychosocial developmental theory. Cadernos de Consulta Psicológica, 2, 23-34.

Marcia, J. E. (1987). The identity status approach to the study of ego identity development. In T. Honess \& K. Yardley (Eds.), Self and identity (pp. 161-171). New York: Routledge \& Kegan Paul.

Martin, F., Sabourin, S., Laplante, B., \& Coallier, J. C. (1991). Diffusion, support, approach, and external barriers as distinct theoretical dimensions of the Career Decision Scale: Disconfirming evidence? Journal of Vocational Behavior, 38, 187-197.

Muuss, R. E. (1996). Theories of adolescence (6th ed.). New York: McGraw-Hill.

Olson, D. H., Sprenkle, D. H., \& Russel, C. S. (1979). Circumplex model of marital and family systems: I. Cohesion and adaptability dimensions of family types and clinical applications. Family Process, 18, 3-28.

Osipow, S. H. (1991). Response to Vondracek, Dorn, and Hackett. Journal of Counseling and Development, 70, 332-333.

Osipow, S. H. (1994). The Career Decision Scale: How good does it have to be? Journal of Career Assessment, 2, 15-18.

Osipow, S. H., Carney, C. G., \& Barak, A. (1976). A scale of educational-vocational undecidedness: A typological approach. Journal of Vocational Behavior, 9, 233-243.

Penick, N. I., \& Jepsen, D. A. (1992). Family functioning and adolescent career development. Career Development Quarterly, 40, 208-222.

Petitpas, A. (1978). Identity foreclosure: A unique challenge. Personnel and Guidance Journal, 56, $558-561$.

Phillips, S. D. (1992). Career counseling: Choice and implementation. In S. D. Brown \& R. W. Lent (Eds.), Handbook of counseling psychology (2nd ed.) (pp. 513-547). New York: Wiley.

Phillips, S. D., \& Pazienza, N. J. (1988). History and theory of the assessment of career development and decision making. In W. B. Walsh \& S. H. Osipow (Eds.), Career decision making (pp. 1-31). Hillsdale, NJ: Erlbaum.

Raskin, P. M. (1985). Identity and vocational development. In A.S. Waterman (Ed.), Identity in adolescence: Processes and contents (pp. 25-42) San Francisco: Jossey-Bass.

Raskin, P. M. (1989). Identity status research: Implications for career counseling. Journal of Adolescence, 12, 375-388.

Rice, K. G. (1992). Separation-individuation and adjustment to college: A longitudinal study. Journal of Counseling Psychology, 39, 203-213.

Rice, K. G., Cole, D. A., \& Lapsley, D. K. (1990). Separation-individuation, family cohesion, and adjustment to college: Measurement validation and test of a theoretical model. Journal of Counseling Psychology, 37, 195-202.

Roe, A. (1957). Early determinants of vocational choice. Journal of Counseling Psychology, 4, 212-217.

Rojewski, J. W. (1994). Career indecision types for rural adolescents from disadvantaged and non disadvantaged backgrounds. Journal of Counseling Psychology, 41, 356-363. 
Sabatelli, R. M., \& Mazor, A. (1985). Differentiation, individuation, and identity formation: The integration of family system and individual developmental perspectives. Adolescence, 20, $619-633$.

Salomone, P. R. (1982). Difficult cases in career counseling: II. The indecisive client. Personnel and Guidance Journal, 60, 496-500.

Santos, P. J. (1997). Adolescência e indecisão vocacional [Adolescence and career indecision]. Unpublished master's thesis, Faculty of Psychology and Education, Porto State University, Portugal.

Savickas, M. L. (1992). New directions in career assessment. In D. H. Montross \& C. J. Shinkman (Eds.), Career development: Theory and practice (pp. 336-355). Springfield, IL: Thomas.

Savickas, M. L., \& Jarjoura, D. (1991). The Career Decision Scale as type indicator. Journal of Counseling Psychology, 38, 85-90.

Schulenberg, J. E., Shimizu, K., Vondracek, F. W., \& Hostetler, M. (1988). Factorial invariance of career indecision dimensions across junior high and high school males and females. Journal of Vocational Behavior, 33, 63-81.

Schulenberg, J. E., Vondracek, F. W., \& Crouter, A. C. (1984). The influence of the family on vocational development. Journal of Marriage and the Family, 46, 129-143.

Sepich, R. T. (1987). A review of the correlates and measurements of career indecision. Journal of Career Development, 14, 8-23.

Shimizu, K., Vondracek, F. W., Schulenberg, J. E., \& Hostetler, M. (1988). The factor structure of the Career Decision Scale: Similarities across selected studies. Journal of Vocational Behavior, 32, 213-225.

Skorikov, V., \& Vondracek, F. W. (1998). Vocational identity development: Its relationship to other identity domains and to overall identity development. Journal of Career Assessment, 6, 13-35.

Slaney, R. B. (1988). The assessment of career decision making. In W. B. Walsh \& S. H. Osipow (Eds.), Career decision making (pp. 33-76). Hillsdale, NJ: Erlbaum.

Super, D. E. (1957). The psychology of careers. New York: Harper \& Row.

Thomason, S. L., \& Winer, J. L. (1994). Career maturity and familial independence among college freshmen. Journal of Career Development, 21, 23-35.

Tinsley, H. E. A. (1992). Career decision making and career indecision [Editorial]. Journal of Vocational Behavior, 41, 209-211.

Tinsley, H. E. A., Bowman, S. L., \& York, D. C. (1989). Career Decision Scale, My Vocational Situation, Vocational Rating Scale, and Decisional Rating Scale: Do they measure the same constructs? Journal of Counseling Psychology, 36, 115-120.

Tyler, L. E. (1969). The work of the counselor (3rd ed.). Englewood Cliffs, NJ: Prentice Hall.

Van de Vijver, F., \& Hambleton, R. K. (1996). Translating tests: Some practical guidelines. European Psychologist, 1, 89-99.

Vondracek, F. W.(1992). The construct of identity and its use in career theory and research. Career Development Quarterly, 41, 130-144.

Vondracek, F. W., Hostetler, M., Schulenberg, J. E., \& Shimizu, K. (1990). Dimensions of career indecision. Journal of Counseling Psychology, 37, 98-106.

Vondracek, F. W., Schulenberg, J., Skorikov, V., Gillespie, L. K., \& Wahlheim, C. (1995). The relationship of identity status to career indecision during adolescence. Journal of Adolescence, 18, 17-29.

Wanberg, C. R., \& Muchinsky, P. M. (1992). A typology of career decision status: Validity extension of the vocational decision status model. Journal of Counseling Psychology, 39, 71-80.

Whiston, S. C. (1996). The relationship among family interactions patterns and career indecision and career indecision-making self-efficacy. Journal of Career Development, 23, 137-149.

Zingaro, J. C. (1983). A family systems approach for the career counselor. Personnel and Guidance Journal, 62, 24-27.

Received: November 30, 1998 